\title{
UPLC/Q-TOF MS Screening and Identification of Antibacterial Compounds in Forsythia suspensa (Thunb.) Vahl Leaves
}

\author{
Mingyue Zhou ${ }^{1,2 \dagger}$, Jinhai Huo ${ }^{1 \dagger}$, Cairen Wang ${ }^{2}$ and Weiming Wang ${ }^{1 *}$ \\ ${ }^{1}$ Institute of Chinese Materia Medica, Heilongjiang Academy of Chinese Medicine Sciences, Harbin, China, ${ }^{2}$ State Key Laboratory \\ of Quality Research in Chinese Medicines, Macau Institute for Applied Research in Medicine and Health, Macau University of \\ Science and Technology, Taipa, China
}

\section{OPEN ACCESS}

Edited by:

Mukhlesur Rahman,

University of East London,

United Kingdom

Reviewed by:

Kunming Qin,

Jiangsu Ocean Universitty, China

Peter G. Ott,

Hungarian Academy of Sciences

(MTA), Hungary

Kaushik Bhattacharjee,

Indian Institute of Technology

Guwahati, India

*Correspondence: Weiming Wang

zyyjy@163.com

these authors have contributed equally to this work

Specialty section:

This article was submitted to Experimental Pharmacology and Drug

Discovery,

a section of the journal

Frontiers in Pharmacology

Received: 02 May 2021 Accepted: 10 December 2021 Published: 28 January 2022

Citation:

Zhou M, Huo J, Wang $C$ and Wang $W$ (2022) UPLC/Q-TOF MS Screening and Identification of Antibacterial Compounds in Forsythia suspensa

(Thunb.) Vahl Leaves.

Front. Pharmacol. 12:704260. doi: 10.3389/fphar.2021.704260
Forsythia suspensa (Thunb.) Vahl (F. suspensa) is a traditional Chinese medical herb and only its fruit is currently used in clinical therapies. However, the discarded parts like leaves also contain a large number of active components. In this study, we used macroporous adsorption resin to enrich the effective components from $F$. suspensa leaves. The separated active compounds were then identified and quantified by ultra-performance liquid chromatography coupled with quadrupole time of flight mass spectrometry (UPLC/ Q-TOF MS) and high-performance liquid chromatography Active components with antibacterial properties extracted from $F$. suspensa leaves were confirmed in vitro and the corresponding mechanisms were explored. In sum, a stable and effective method for extracting antibacterial active components from $F$. suspensa leaves was established in this study, which proved the practicability of $F$. suspensa leaves as traditional Chinese medicine and is conducive to the more comprehensive utilization of the plant.

Keywords: F suspensa leaves, chemical profiling, antibacterial mechanism, UPLC/Q-TOF MS, S. aureus and E. coli

\section{INTRODUCTION}

The fruit of Forsythia suspensa (Thunb.) Vahl (F. suspensa) has been widely used in clinical settings. However, the leaves of Forsythia suspensa receives little attention, in spite of their great medicinal value. Currently, F. suspensa leaves are mainly used for the treatment of pyrexia, inflammation, gonorrhea, carbuncle, and erysipelas. Modern pharmacological research has revealed that its pharmacological effects include anti-inflammatory, antioxidant, antibacterial, anti-cancer, antivirus, anti-allergy, neuroprotective functions (Chen et al., 1999; Kim et al., 2003; Han et al., 2012; Lee et al., 2017; Wang et al., 2018). However, F. suspensa leaves are in large discarded during the harvesting process, which causes a waste of potentially valuable resources. It has been found that phenethyl alcohol glycosides are the main active components in the fruits of $F$. suspensa and play an antibacterial role, while the components in fruits and leaves are almost the same. In addition, the contents of forsythoside $\mathrm{A}$, forsythin, and rutin in leaves are much higher than those in fruits, indicating that leaves could also possess an antibacterial effect in vitro (Tian et al., 2021). Thus, the by-products from the processing of $F$. suspensa leaves can play a key role in our daily lives, such as antibacterial hand sanitizer additives and health functional drinks. The use of non-medicinal parts will promote the comprehensive utilization of medicinal plants and reduce resource waste. However, there is limited research on the antibacterial active substances in the leaves of $F$. suspensa, and the antibacterial mechanism is not clearly defined, which limits their applications. Therefore, a stable and 


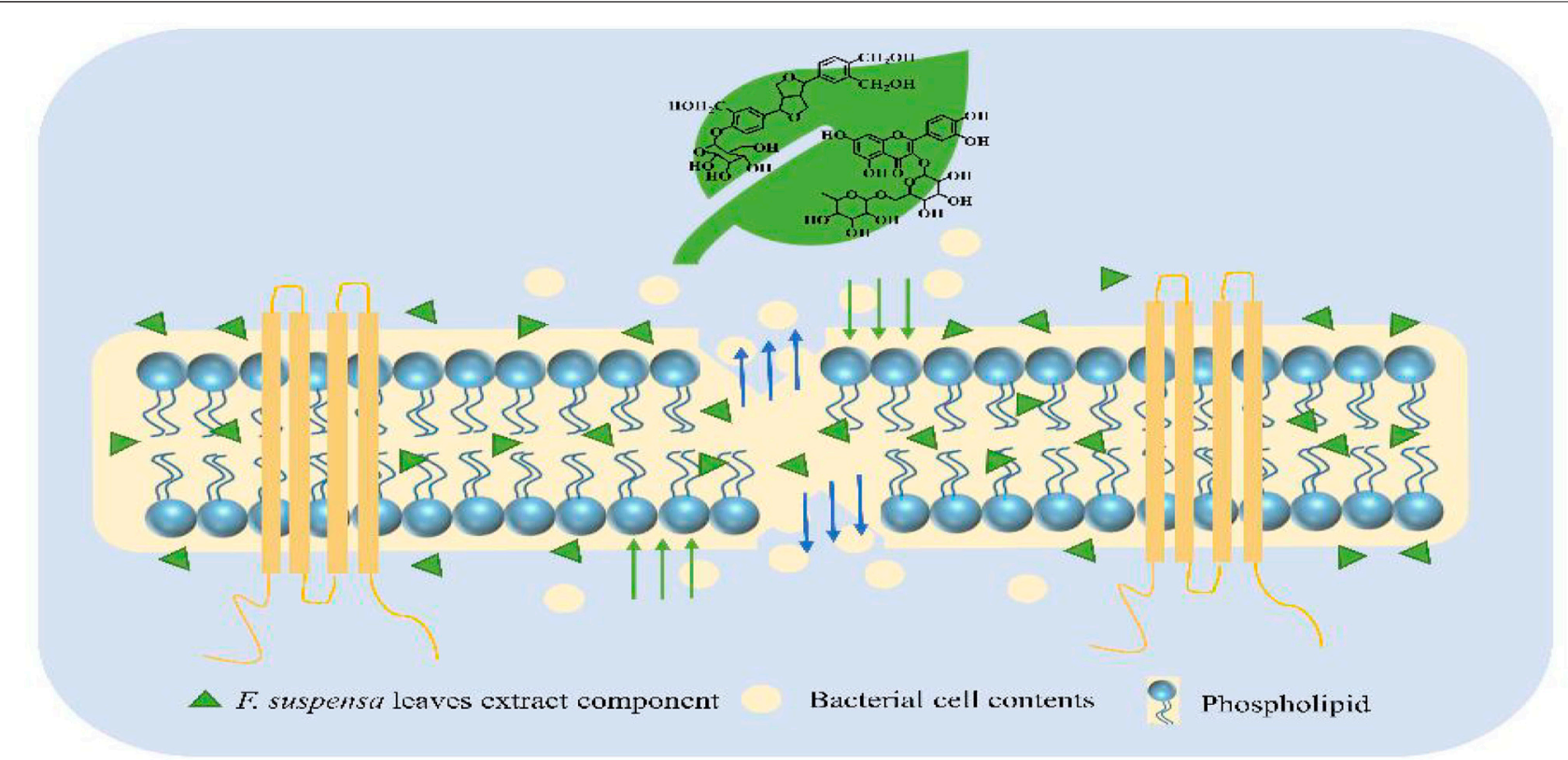

FIGURE 1 | Antibacterial mechanism of $F$. suspensa leaves extract.

effective method for extracting antibacterial active ingredients from $F$. suspensa leaves using macroporous adsorption resin (MARs) was developed, and the antibacterial mechanism was discussed (Figure 1). The development and utilization of resources of non-medicinal parts of traditional Chinese medicine is a sustainable concept. The full use of $F$. suspensa leaves will improve production efficiency and avoid environmental pollution.

\section{EXPERIMENTAL SECTION}

\section{Instruments and Materials Instruments}

The UPLC/Q-TOF MS analyses were performed on an AB SCIEX Triple-TOFTM $5600^{+}$mass spectrometer and ExionLC AD (AB Sciex, MA, USA). The HPLC analyses were performed on Shimadzu 2010 CH HPLC system (Shimadzu, Japan). The vertical automatic high-pressure steam sterilization pot was used for the bacteria experiment (LDZX-75KB, Shanghai Shenan Medical Instrument Factory, China). Nitrogen blowing was carried out on a CM-12J type nitrogen blowing instrument (Beijing Chengmeng Weiye Technology Co., Ltd., China). A scanning electron microscope (SEM) Hitachi S-3400N equipped with an X-radiation detector EDS (Voyager of noran instruments). Gold thin films and nanoparticles were prepared by an ion coater (Eiko IB3, Tokyo, Japan). UV-visible spectrometry and multi-function microplate reader were used (TECAN Corporation, Austria). Reverse transcription polymerase chain reaction (RT-PCR) amplifications were performed on LineGene 9660 model FQD-96A (Hangzhou Bori Technology Co., Ltd., China).

\section{Chemical Regents}

AB-8 MARs were purchased from Suzhou Donghong Chemical Co., Ltd (Suzhou, China). HPLC-grade ethanol, methanol, and acetonitrile were purchased from Merck (Merck, Germany). Gentamicin sulfate injection was purchased from Henan Runhong Pharmaceutical Co., Ltd (Henan, China). 2.5\% EM grade glutaraldehyde was purchased from AGAR Scientific (AGAR, United Kingdom). TRIzol ${ }^{\mathrm{TM}}$ reagent was purchased from Thermo Fisher Scientific (Thermo, United States). Water was purchased from Guangzhou Watsons Food \& Beverage Co., Ltd (Guangzhou, China) and phosphate-buffered saline (PBS) was purchased from Invitrogen Co. Carlsbad (Invitrogen, United States). Dimethyl sulfoxide (DMSO) was purchased from Sigma-Aldrich Company Ltd. (St. Louis, United States). Forsythiaside A, forsythin, chlorogenic acid, and rutin standard ( $\geq 98 \%$ purity, HPLC) (National Institute for the Control of Pharmaceutical and Biological Products, China). Reverse transcription kit and Real-Time PCR kit were purchased from Takara Biotechnology Co., Ltd (Takara, China) and an alkaline phosphatase assay (AKP) Kit was purchased from MyBioSource, Inc (MyBioSource, United States). Mueller-Hinton (MH) agar medium, MH broth medium, and Lysogeny broth (LB) broth were prepared according to the manufacturer's instructions and purchased from Qingdao Gaokeyuan Haibo Biotechnology Co., Ltd (Qingdao, China).

\section{Bacterial Strains}

The Escherichia coli (E. coli) O157:H7 (CICC 10899) and Staphylococcus aureus (S. aureus) (CICC 21601) strains were obtained from the China Center of Industrial Culture Collection (Beijing, China). 
TABLE 1 | RT-PCR reaction conditions.

\begin{tabular}{llcc}
\hline Cycle & \multicolumn{1}{c}{ Step } & Conditions & No. of cycles \\
\hline 1 & Pre-denaturation & $95 \mathrm{C}$ for $30 \mathrm{~s}$ & 1 \\
2 & Denature & $95 \mathrm{C}$ for $5 \mathrm{~s}$ & 40 \\
& Anneal/Collect Date & $60 \mathrm{C}$ for $30 \mathrm{~s}$ & \\
& Extend & $72 \mathrm{C}$ for $30 \mathrm{~s}$ & 1
\end{tabular}

\section{Plant Material}

The F. suspensa leaves were collected in May 2019 from Tunliu County, Shanxi Province, and identified as F. suspensa leaves by Jinhai Huo (Heilongjiang Provincial Academy of Traditional Chinese Medicine, Harbin city, China). Finally, the leaves were picked and dried in a ventilated place.

\section{Adsorption of Phenethyl Alcohol Glycosides on the Resins}

We modified a method of Sun partially and obtained a stable method for enriching phenethyl alcohol glycosides in leaves (Jianrui et al., 2017). A total of $50.0 \mathrm{~g}$ leaves were accurately weighed and immersed in $600 \mathrm{ml}$ water for $2 \mathrm{~h}$, then reflux extraction was performed twice for $2 \mathrm{~h}$ each time. The extracts were combined in a rotary evaporator and evaporated to dryness, and then reconstituted with water to obtain $50 \mathrm{ml}$ of sample solution. The MARs were pretreated by soaking in 95\% ethanol overnight and then washed with water thoroughly to remove ethanol completely. A $4.2 \mathrm{~cm} \times 100 \mathrm{~cm}$ glass column filled with $500 \mathrm{~g} \mathrm{AB}-8$ resin, which was used in the gradient elution tests with the flow rate is two bed volumes (BV)/h. Then the adsorbateladen column was first washed with water and eluted with ethanol-water solutions of $10,30,50$, and $70 \%$ in succession (represented by $\mathrm{A}, \mathrm{B}, \mathrm{C}, \mathrm{D}$, and $\mathrm{E}$, respectively). The elution solution from each gradient elution solution was collected to the rotary evaporator and evaporated to dryness and dissolved in $100 \mathrm{ml}$ water.

\section{HPLC, and UPLC/Q-TOF MS Analysis}

Sample preparation for HPLC: The forsythiaside A standard was dissolved in methanol to prepare a sample with a concentration of $0.106 \mathrm{mg} / \mathrm{ml}$. The A, B, C, D, and E elution were concentrated 5 times and filtered to obtain the test solution $(0.45 \mu \mathrm{m}$ water filter membrane (Tianjin Jinteng Experimental Equipment Co., Ltd.)). HPLC performance parameters were in the Supplementary Material.

HPLC analysis: The chromatographic system is equipped with a quaternary gradient pump, online degasser, autosampler, column thermostat, and Shimadzu liquid chromatography workstation. The chromatographic separation was performed on an Agilent ZORBAX $\mathrm{C}_{18}$ column $(4.6 \mathrm{~mm} \times$ $250 \mathrm{~mm}, 5 \mu \mathrm{m})$. Methanol-0.8\% glacial acetic acid was used as the mobile phase, the flow rate was $0.8 \mathrm{ml} / \mathrm{min}$. The detection wavelength was $280 \mathrm{~nm}$, the injection volume was $10 \mu \mathrm{L}$, and the column temperature was $30^{\circ} \mathrm{C}$. The solvent gradient adopted was as follows: $0-6 \mathrm{~min}, 85 \%-74 \% \mathrm{~B} ; 6-20 \mathrm{~min}, 74 \% \mathrm{~B} ; 20-25$ min, 74\%-70\% B; 25-30 min, 70\%-63\% B; 30-45 min, 63\% B; 45-60 min, 63\%-61\% B.

Sample preparation for UPLC/Q-TOF MS: Standards of forsythin, chlorogenic acid, and rutin were dissolved in methanol solution to prepare a sample with a concentration of 95, 304, $138 \mu \mathrm{g} / \mathrm{ml}$. The C elution solution (FC) was diluted 5 times and filtered $(0.22 \mu \mathrm{m}$ water filter membrane (Tianjin Jinteng Experimental Equipment Co., Ltd.)).

UPLC/Q-TOF MS analysis: The chromatographic separation was performed on a Waters ACQUITY UPLC BEH $\mathrm{C}_{18}$ column with $1.7 \mu \mathrm{m}, 2.1 \mathrm{~mm} \times 100 \mathrm{~mm}$, and equipped a $\mathrm{BEH} \mathrm{C}_{18}$ VanGuard Pre-Column with $1.7 \mu \mathrm{m}, 5 \mathrm{~mm} \times 2.1 \mathrm{~mm}$, from the same supplier. The composition of the two mobile phases was $0.1 \%(\mathrm{v} / \mathrm{v})$ formic acid in water (A) and acetonitrile (B): 0-5 min, $5 \%-25 \% \mathrm{~B}$; 3-13 min, 25\%-80\% B; 13-23 min, $80 \%-100 \% \mathrm{~B}$; 23-23.1 min, $100 \%-5 \% \mathrm{~B} ; 23.1-25 \mathrm{~min}, 5 \% \mathrm{~B}$. The separations were performed with a constant flow rate of $300 \mu \mathrm{L} / \mathrm{min}$. The column oven and tray cooler temperatures were set to 30 and $4{ }^{\circ} \mathrm{C}$, respectively. $5 \mu \mathrm{L}$ of samples were injected in a full loop injection mode. The electrospray MS detection was performed in positive and negative mode detection mode with the ion source voltage set to $5.5 \mathrm{kV} / 4.5 \mathrm{kV}$. Nitrogen was used as the sheath gas and helium as auxiliary gas with a flow rate of 10 and 0 arbitrary units, respectively. The mass spectrum scanning range is $80-1500 \mathrm{Da}$. The $80 \mathrm{~V}$ declustering potential, $35 \mathrm{eV} /-35 \mathrm{eV}$ collision energy, and $15 \mathrm{eV} /-15 \mathrm{eV}$ collision energy spread were used in mass detection. PeakView 2.0 was used to load published compounds into the MasterView function block for analysis.

\section{Antibacterial Potential}

A standard agar disc diffusion method was used for the antibacterial assay. A standardized inoculum $(100 \mu \mathrm{L})$ containing $10^{7} \mathrm{CFU} / \mathrm{ml}$ bacterial suspension was prepared by diluting an overnight culture in LB broth, and then spread evenly on the LB agar plate. Filter paper (6 mm diameter) was impregnated with $20 \mu \mathrm{L}$ of FC and gentamicin sulfate injection $(0.16 \mathrm{mg} / \mathrm{ml})$ placed on inoculated agar, and incubated at $37^{\circ} \mathrm{C}$ for $24 \mathrm{~h}$. The antibacterial activity was evaluated by measuring the diameter of the inhibition zone against the tested bacteria.

The minimum inhibitory concentrations (MICs) and minimum bactericidal concentrations (MBCs) of FC were determined by the method of two-fold broth micro-dilution (Mellegard et al., 2011). The strains with a concentration of $10^{7} \mathrm{CFU} / \mathrm{ml}(100 \mathrm{uL})$ were added to each well of a 96-well plate containing $100 \mathrm{uL}$ of serially diluted FC in $\mathrm{MH}$ broth. After incubating at $37 \mathrm{C}$ with shaking for $24 \mathrm{~h}$, the MICs were obtained by measuring the optical density (OD) at $600 \mathrm{~nm}$. Furthermore, the aliquots from wells displaying no growth were spread on nutrient agar plates and incubated at $37^{\circ} \mathrm{C}$ for $24 \mathrm{~h}$. Compared with the initial bacterial inoculum, the lowest concentration of the sample solution in the well that reduced the growth of bacteria on the agar plate by $99.9 \%$ was expressed as $\mathrm{MBC}$.

The viable counts of tested bacteria were determined based on J Han's detection method (Han et al., 2017). The FC at the MIC level was used to inoculate a bacterial suspension containing $10^{7} \mathrm{CFU} / \mathrm{ml}$ and incubate at $37^{\circ} \mathrm{C}$ with a $150 \mathrm{r} / \mathrm{min}$ shaking 

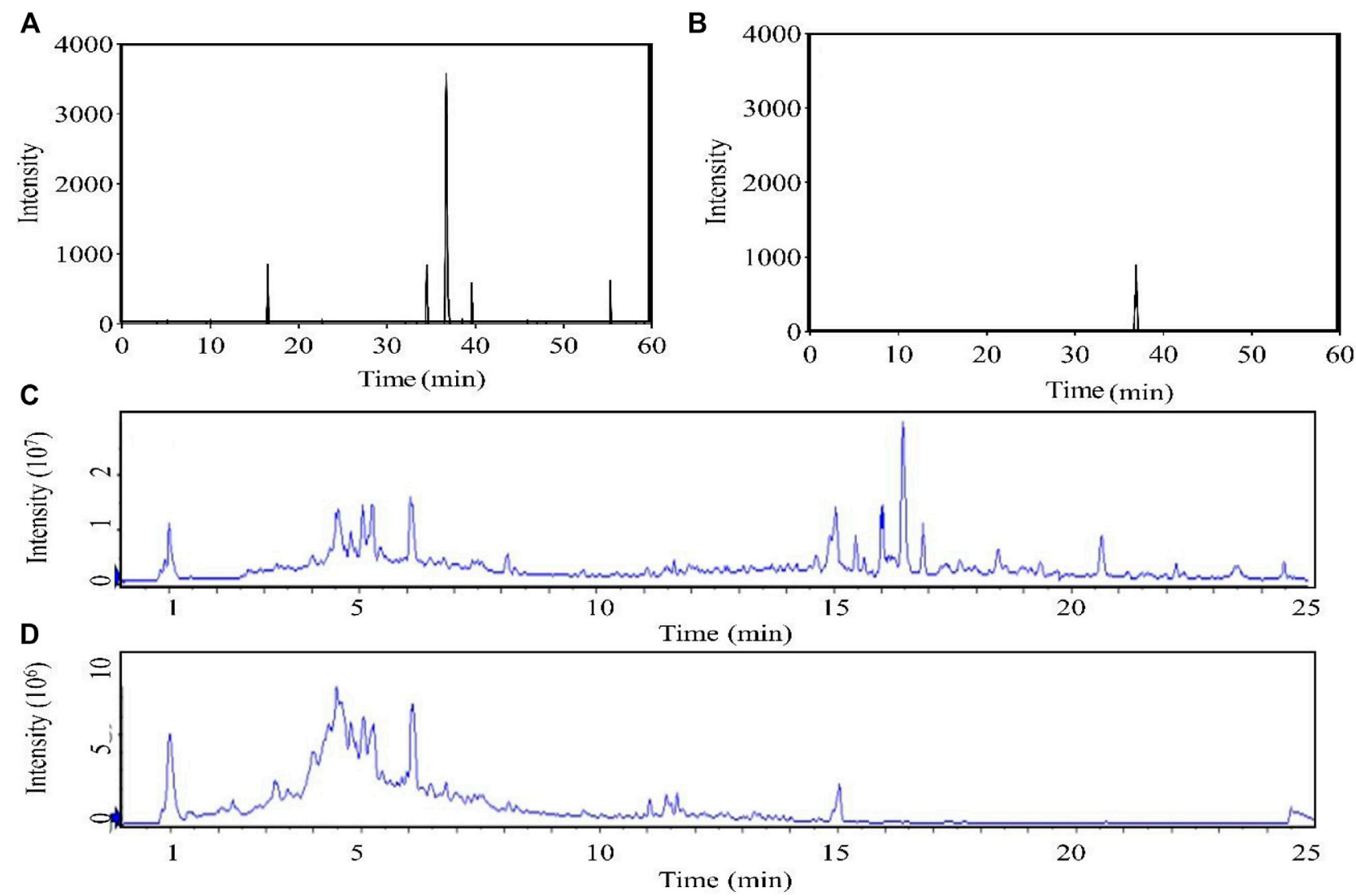

FIGURE 2 | Chromatogram (A): HPLC chromatogram. (B): HPLC chromatogram of forsythiaside A standard. The total ion chromatogram obtained in the positive (C) and negative (D) modes.).

incubator for viable bacteria count. At $0,20,40,60,90,120,150$, 210 , and $300 \mathrm{~min}, 50 \mu \mathrm{L}$ of bacterial suspension was applied to the surface of the $\mathrm{MH}$ nutrient agar which incubates in a $37^{\circ} \mathrm{C}$ incubator for $24 \mathrm{~h}$ and counts. $10^{7} \mathrm{CFU} / \mathrm{ml}$ text bacterial suspension was mixed with the $\mathrm{FC}$ to make the final concentration of $\mathrm{MIC}$, and cultured at $37^{\circ} \mathrm{C}, 150 \mathrm{r} / \mathrm{min}$ shakers, with sterile water as a blank group. The OD value of the solution at $600 \mathrm{~nm}$ was measured by a spectrophotometer every $2 \mathrm{~h}$ (Filippini et al., 2011).

\section{Antibacterial Mechanisms}

Effect on morphological changes: The state of the bacterial cell membrane treated with FC was observed by SEM. S. aureus and E. coli were respectively inoculated on $\mathrm{MH}$ and $\mathrm{LB}$ agar containing FC (at concentrations of both MIC and 2MIC), and cultured in a $37^{\circ} \mathrm{C}$ incubator for $24 \mathrm{~h}$. The specimens were collected and fixed in $2.5 \%(\mathrm{v} / \mathrm{v})$ glutaraldehyde for $8 \mathrm{~h}$, and then continuously exposed to ethanol in a concentration range of $30-100 \%$ to dehydrate the samples. The ethanol was replaced by $100 \%$ tertiary butyl alcohol. The specimens were dried with $\mathrm{CO}_{2}$ and the dried cells were coated with gold in a sputter coater after dehydration.

Effect on cell wall permeability: According to Juan Xie's method, the AKP kit was used to detect cell wall permeability
(Qiang et al., 2014). Each $10 \mathrm{ml}$ centrifuge tube containing a bacterial suspension (approximately $10^{5} \mathrm{CFU} / \mathrm{ml}$ ) in $2 \mathrm{ml}$ of $\mathrm{LB}$ broth was inoculated with the MIC level of FC and incubated at $37^{\circ} \mathrm{C}$ and $150 \mathrm{r} / \mathrm{min}$ in a shaking incubator. In addition, the sample was replaced with sterile water as a blank group. After mixing and culturing, $1 \mathrm{ml}$ of the bacterial suspension was centrifuged at $3,500 \mathrm{r} / \mathrm{min}$ for $10 \mathrm{~min}$. The absorbance of the supernatant was measured every $2 \mathrm{hs}$ at $680 \mathrm{~nm}$ by a microplate reader.

Effect on membrane integrity: The FC at the MIC level was added to the tube with the bacterial inoculum. The cells were centrifuged at $3,500 \mathrm{r} / \mathrm{min}$ after $0,60,120,180,240,300$, and $360 \mathrm{~min}$ of treatment, and the absorbance of the obtained supernatant was determined at $260 \mathrm{~nm}$ by a microplate reader (Xiao-fang et al., 2016).

Effect on membrane efflux pump gene expression: Total RNA samples were isolated from the bacterial cells using the TRIzol $^{\mathrm{TM}}$ reagent (Monteiro et al., 2016). Reverse transcription of RNA was performed according to manufacturer instructions of the TaKaRa Reverse transcription Kit. The relative expression of bacterial cell membrane efflux pump genes was determined by the $2^{-\Delta \Delta C t}$ method using quantitative RT-PCR (Livak and Schmittgen, 2001). Approximately $2 \mu \mathrm{g}$ RNA (>200 nt) was reversely transcribed for cDNA 
TABLE 2 | Components of FC of $F$. suspensa leaves.

\begin{tabular}{|c|c|c|c|c|c|c|c|c|c|}
\hline No & $\begin{array}{c}\text { RT } \\
(\min )\end{array}$ & $\begin{array}{l}\text { Extracting } \\
\text { ions }\end{array}$ & $\begin{array}{l}\text { Measured } \\
\text { mass }(\mathrm{m} / \mathrm{z})\end{array}$ & $\begin{array}{l}\text { Error } \\
\text { (ppm) }\end{array}$ & Formula & $\begin{array}{l}\text { Main secondary } \\
\text { fragment ions } \\
\text { (MS/MS) and } \\
\text { sources }\end{array}$ & Identity & Category & Cas no \\
\hline 1 & 1.2 & {$[\mathrm{M}+\mathrm{H}]^{+}$} & 123.0563 & 8.9 & $\mathrm{C}_{14} \mathrm{H}_{20} \mathrm{O}_{8}$ & $\begin{array}{c}317,299,281 \\
263,227,217 \\
203,161\end{array}$ & $\begin{array}{l}\text { 4-hydroxy-4-[2-[(2S,3S,4R,5R,6S)- } \\
\text { 3,4,5-trihydroxy-6-(hydroxymethyl) } \\
\text { oxan-2-yl] oxyethyl] cyclohexa-2,5- } \\
\text { dien-1-one }\end{array}$ & Glycosides & $40661-45-8$ \\
\hline 2 & 3.4 & {$[\mathrm{M}+\mathrm{H}]^{+}$} & 155.0697 & 3.7 & $\mathrm{C}_{8} \mathrm{H}_{10} \mathrm{O}_{3}$ & $\begin{array}{l}155,109,96 \\
95,91\end{array}$ & $\begin{array}{l}\text { 3a-hydroxy-2,3,7,7a-tetrahydro-1- } \\
\text { benzofuran-6-one }\end{array}$ & Other & $94535-01-0$ \\
\hline 3 & 4.1 & {$[\mathrm{M}+\mathrm{H}]^{+}$} & 361.1663 & 4.8 & $\mathrm{C}_{20} \mathrm{H}_{24} \mathrm{O}_{6}$ & $\begin{array}{c}361,343,315 \\
152,134\end{array}$ & Lariciresinol & Glycosides & 27003-73-2 \\
\hline 4 & 4.4 & {$[\mathrm{M}+\mathrm{H}]^{+}$} & 127.0387 & 2.1 & $\mathrm{C}_{6} \mathrm{H}_{6} \mathrm{O}_{3}$ & $127,109,81$ & Benzene-1,2,4-triol & Phenolic & $533-73-3$ \\
\hline 5 & 5.1 & {$[\mathrm{M}+\mathrm{H}]^{+}$} & 163.0750 & 2.2 & $\mathrm{C}_{10} \mathrm{H}_{10} \mathrm{O}_{2}$ & $163,131,103$ & Safrole & Phenylpropanoid & $94-59-7$ \\
\hline 6 & 5.3 & {$[\mathrm{M}+\mathrm{H}]^{+}$} & 463.1232 & 0.6 & $\mathrm{C}_{22} \mathrm{H}_{22} \mathrm{O}_{11}$ & $\begin{array}{c}463,355,337 \\
309,295,205 \\
187,169,151 \\
133,127\end{array}$ & Tectoridin & Flavonoids & $611-40-5$ \\
\hline 7 & 5.5 & {$[\mathrm{M}+\mathrm{H}]^{+}$} & 355.1024 & 0.1 & $\mathrm{C}_{16} \mathrm{H}_{18} \mathrm{O}_{9}$ & $355,163,145,117$ & Chlorogenic acid & Organic acids & $327-97-9$ \\
\hline 8 & 6.5 & {$[\mathrm{M}+\mathrm{H}]^{+}$} & 521.2014 & 0.7 & $\mathrm{C}_{26} \mathrm{H}_{32} \mathrm{O}_{11}$ & $\begin{array}{c}521,163,161 \\
137,103\end{array}$ & $\begin{array}{l}\text { (3R,4R)-4-[(4-hydroxy-3- } \\
\text { methoxyphenyl) methyl]-3-[[3- } \\
\text { methoxy-4-[(2S,3R,4S,5S,6R)-3,4,5- } \\
\text { trihydroxy-6-(hydroxymethyl) oxan-2- } \\
\text { yl] oxyphenyl] methyl] oxolan-2-one }\end{array}$ & Glycosides & 23202-85-9 \\
\hline 9 & 7.9 & {$[\mathrm{M}+\mathrm{H}]^{+}$} & 303.0500 & 0.2 & $\mathrm{C}_{15} \mathrm{H}_{10} \mathrm{O}_{7}$ & $\begin{array}{c}303,285,257 \\
229,201,165 \\
153,137\end{array}$ & Quercetin & Flavonoids & $117-39-5$ \\
\hline 10 & 8.0 & {$[\mathrm{M}+\mathrm{H}]^{+}$} & 465.1028 & 0.1 & $\mathrm{C}_{21} \mathrm{H}_{20} \mathrm{O}_{12}$ & $\begin{array}{c}465,303,285 \\
257,229\end{array}$ & Quercetin 3- $\beta$-D-glucoside & Flavonoids & $482-35-9$ \\
\hline 11 & 8.6 & {$[\mathrm{M}+\mathrm{H}]^{+}$} & 449.1082 & 0.8 & $\mathrm{C}_{21} \mathrm{H}_{20} \mathrm{O}_{11}$ & $449,287,165$ & Kaempferol 3-O-glucoside & Flavonoids & $480-10-4$ \\
\hline 12 & 8.6 & {$[\mathrm{M}+\mathrm{H}]^{+}$} & 287.0552 & 0.7 & $\mathrm{C}_{15} \mathrm{H}_{10} \mathrm{O}_{6}$ & $\begin{array}{l}287,241,213 \\
185,171,165 \\
157,121,107\end{array}$ & Kaempferol & Flavonoids & $520-18-3$ \\
\hline 13 & 8.6 & {$[\mathrm{M}+\mathrm{H}]^{+}$} & 479.1549 & 0.2 & $\mathrm{C}_{23} \mathrm{H}_{26} \mathrm{O}_{11}$ & $\begin{array}{c}479,325,263 \\
245,163,145,117\end{array}$ & Calceolarioside B & Glycosides & $105,471-98-5$ \\
\hline 14 & 8.7 & {$[\mathrm{M}+\mathrm{H}]^{+}$} & 181.0487 & 4.6 & $\mathrm{C}_{9} \mathrm{H}_{8} \mathrm{O}_{4}$ & $181,163,145,135$ & Cis-caffeic acid & Organic acids & $331-39-5$ \\
\hline 15 & 11.5 & {$[\mathrm{M}+\mathrm{H}]^{+}$} & 321.0606 & 0.3 & $\mathrm{C}_{15} \mathrm{H}_{12} \mathrm{O}_{8}$ & $\begin{array}{c}321,303,257 \\
229,213,169 \\
141,123\end{array}$ & Dihydromyricetin & Flavonoids & $27200-12-0$ \\
\hline 16 & 11.6 & {$[\mathrm{M}+\mathrm{H}]^{+}$} & 359.1486 & 0.9 & $\mathrm{C}_{20} \mathrm{H}_{22} \mathrm{O}_{6}$ & $\begin{array}{c}359,341,311 \\
205,151,137,122\end{array}$ & Terpineol & Lignans & $8,006-39-1$ \\
\hline 17 & 14.4 & {$[\mathrm{M}+\mathrm{H}]^{+}$} & 447.0925 & 0.1 & $\mathrm{C}_{21} \mathrm{H}_{18} \mathrm{O}_{11}$ & 447,271 & $\begin{array}{l}\text { 6-(5,6-dihydroxy-4-oxo-2- } \\
\text { phenylchromen-7-yl)oxy-3,4,5- } \\
\text { trihydroxyoxane-2-carboxylic acid }\end{array}$ & Glycosides & $100,647-26-5$ \\
\hline 18 & 5.1 & {$[\mathrm{M}-\mathrm{H}]^{-}$} & 299.1130 & 2.1 & $\mathrm{C}_{14} \mathrm{H}_{20} \mathrm{O}_{7}$ & $\begin{array}{c}299,165,151 \\
137,119\end{array}$ & Salidroside & Glycosides & $10338-51-9$ \\
\hline 19 & 5.1 & {$[\mathrm{M}-\mathrm{H}]^{-}$} & 137.0246 & 1.3 & $\mathrm{C}_{7} \mathrm{H}_{6} \mathrm{O}_{3}$ & $137,119,109$ & 3,4-dihydroxybenzaldehyde & Phenolic & $139-85-5$ \\
\hline 20 & 5.5 & {$[\mathrm{M}-\mathrm{H}]^{-}$} & 389.1442 & 2.6 & $\mathrm{C}_{17} \mathrm{H}_{26} \mathrm{O}_{10}$ & $389,223,181,150$ & Loganin & Glycosides & 18524-94-2 \\
\hline 21 & 5.7 & {$[\mathrm{M}-\mathrm{H}]^{-}$} & 537.1966 & 2.1 & $\mathrm{C}_{26} \mathrm{H}_{34} \mathrm{O}_{12}$ & $\begin{array}{c}537,375,345 \\
327,297,282,279\end{array}$ & $\begin{array}{l}\text { (+)-8'-hydroxyariciresinol 4'-O- } \\
\beta \text {-D-glucopyranoside }\end{array}$ & Glycosides & $76880-93-8$ \\
\hline 22 & 6.5 & {$[\mathrm{M}-\mathrm{H}]^{-}$} & 191.0561 & 0.1 & $\mathrm{C}_{7} \mathrm{H}_{12} \mathrm{O}_{6}$ & $191,127,109$ & Quinic acid & Organic acids & $36413-60-2$ \\
\hline 23 & 7.6 & {$[\mathrm{M}-\mathrm{H}]^{-}$} & 609.1817 & 1.3 & $\mathrm{C}_{28} \mathrm{H}_{34} \mathrm{O}_{15}$ & $\begin{array}{c}609,447,419 \\
301,271,179,161\end{array}$ & Hesperidin & Flavonoids & $520-26-3$ \\
\hline 24 & 7.8 & {$[\mathrm{M}-\mathrm{H}]^{-}$} & 609.1467 & 1.0 & $\mathrm{C}_{27} \mathrm{H}_{30} \mathrm{O}_{16}$ & $\begin{array}{c}609,301,271 \\
255,243,178,151\end{array}$ & Rutin & Flavonoids & $168,111-03-3$ \\
\hline 25 & 8.2 & {$[\mathrm{M}-\mathrm{H}]^{-}$} & 755.2409 & 0.7 & $\mathrm{C}_{34} \mathrm{H}_{44} \mathrm{O}_{19}$ & $755,623,593,161$ & $\begin{array}{l}\text { 2-(((3,4-dihydroxy-4-(hydroxymethyl) } \\
\text { tetrahydrofuran-2-yl) oxy) methyl)-6- } \\
\text { (3,4-dihydroxyphenethoxy)-5- } \\
\text { hydroxy-4-((3,4,5-trihydroxy-6- } \\
\text { methyltetrahydro-2H-pyran-2-yl) oxy) } \\
\text { tetrahydro-2H-pyran-3-yl (E)-3-(3,4- } \\
\text { dihydroxyphenyl) acrylate }\end{array}$ & Glycosides & $81525-13-5$ \\
\hline 26 & 8.6 & {$[\mathrm{M}-\mathrm{H}]^{-}$} & 623.1978 & 0.5 & $\mathrm{C}_{29} \mathrm{H}_{36} \mathrm{O}_{15}$ & $\begin{array}{c}624,461,443 \\
179,161\end{array}$ & Forsythoside A & Glycosides & 79916-77-1 \\
\hline 27 & 16.1 & {$[\mathrm{M}-\mathrm{H}]^{-}$} & 371.1499 & 0.3 & $\mathrm{C}_{21} \mathrm{H}_{24} \mathrm{O}_{6}$ & $\begin{array}{c}371,356,151 \\
136,121\end{array}$ & Arctigenin & Lignans & 26687-82-1 \\
\hline
\end{tabular}


TABLE 2 | (Continued) Components of FC of $F$. suspensa leaves.

\begin{tabular}{|c|c|c|c|c|c|c|c|c|c|}
\hline No & $\begin{array}{c}\text { RT } \\
(\min )\end{array}$ & $\begin{array}{l}\text { Extracting } \\
\text { ions }\end{array}$ & $\begin{array}{l}\text { Measured } \\
\text { mass }(\mathrm{m} / \mathrm{z})\end{array}$ & $\begin{array}{l}\text { Error } \\
\text { (ppm) }\end{array}$ & Formula & $\begin{array}{l}\text { Main secondary } \\
\text { fragment ions } \\
\text { (MS/MS) and } \\
\text { sources }\end{array}$ & Identity & Category & Cas no \\
\hline 28 & 18.4 & {$[\mathrm{M}-\mathrm{H}]^{-}$} & 163.0763 & 1 & $\mathrm{C}_{10} \mathrm{H}_{12} \mathrm{O}_{2}$ & $163,148,119$ & Engenol & Phenolic & $97-53-0$ \\
\hline 29 & 23.1 & {$[\mathrm{M}-\mathrm{H}]^{-}$} & 471.3475 & 1 & $\mathrm{C}_{30} \mathrm{H}_{48} \mathrm{O}_{4}$ & 471,407 & Corosolic acid & Terpenoid & $4,547-24-4$ \\
\hline 30 & 5.1 & {$[\mathrm{M}+\mathrm{Na}]^{+}$} & 485.1625 & 0.9 & $\mathrm{C}_{20} \mathrm{H}_{30} \mathrm{O}_{12}$ & 485,339 & Forsythoside E & Glycosides & $93675-88-8$ \\
\hline 31 & 7.8 & {$[\mathrm{M}+\mathrm{Na}]^{+}$} & 557.1945 & 8.6 & $\mathrm{C}_{27} \mathrm{H}_{34} \mathrm{O}_{11}$ & $\begin{array}{l}557,395,379 \\
309,201,185\end{array}$ & Forsythin & Lignans & $96420-61-0$ \\
\hline
\end{tabular}

TABLE 3 | Inhibition zone diameter $(n=3)$.

\begin{tabular}{|c|c|c|c|c|}
\hline \multicolumn{3}{|c|}{ Concentration of $\mathrm{FC}(\mathrm{g} / \mathrm{ml})$} & \multirow[t]{2}{*}{ Forsythiaside a $(5 \mathrm{mg} / \mathrm{ml})$} & \multirow[t]{2}{*}{ Gentamicin $(0.16 \mathrm{mg} / \mathrm{ml})$} \\
\hline 0.05 & 0.10 & 0.50 & & \\
\hline $9.36 \pm 0.10$ & $12.22 \pm 0.32$ & $16.77 \pm 0.26$ & $17.88 \pm 0.01$ & $18.47 \pm 0.13$ \\
\hline $10.23 \pm 0.15$ & $14.41 \pm 0.13$ & $17.56 \pm 0.12$ & $18.14 \pm 0.17$ & $20.28 \pm 0.13$ \\
\hline
\end{tabular}
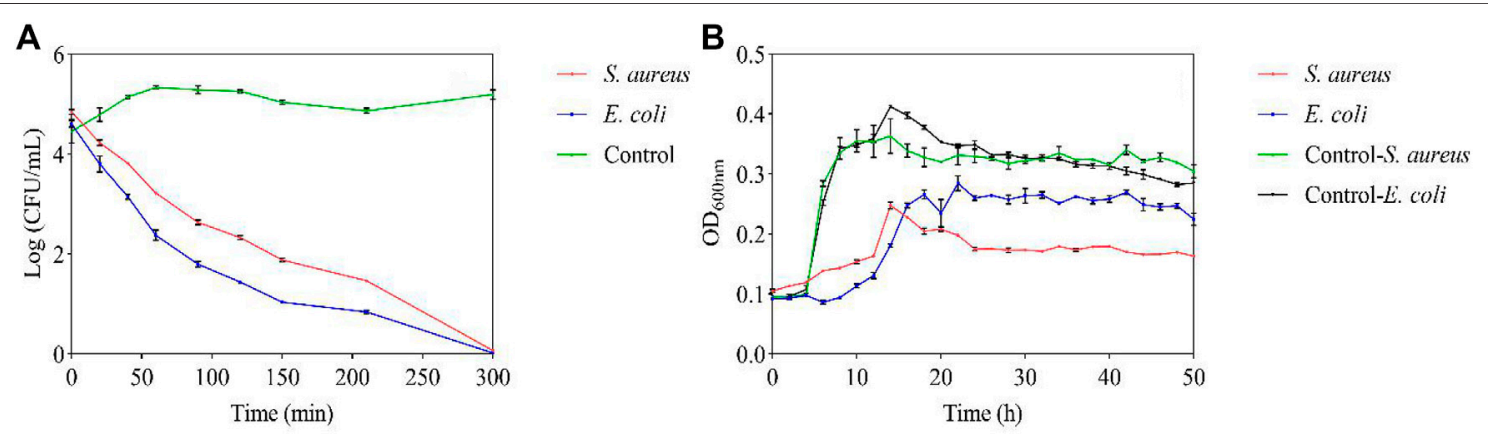

FIGURE 3 | Antibacterial potential of FC at MIC (A): Viable counts. (B): Growth curve).

synthesis by TaKaRa Reverse Kit. The primer sequences were as follows: 16sRNA (forward primer: $5^{\prime}$-CTCCTACGGGAG GCAGCAG-3', reverse primer: $5^{\prime}$-GWATTACCGCGGCKGCTG$3^{\prime}$ ), acrA (forward primer: $5^{\prime}$-ATCGCAGAAGTTCGTCCTCAA GTTAG-3', reverse primer: $5^{\prime}$-ATCGCAGAAGTTCGTCCTCAA GTTAG- $3^{\prime}$ ), and norA (forward primer: $5^{\prime}$-TCTTGCTAGGTA GTGTATCGTCTGGAG-3', reverse primer: $5^{\prime}$-CTTGTA TGGAGGCGGCTTGACC- $3^{\prime}$ ). PCR reaction conditions are summarized in Table 1:

After the reaction, the RT-PCR amplification curves and splitting curves were observed and derived, and the $\mathrm{Ct}$ values of each group were output, and the reverse transcription polymerase chain reaction products were analyzed.

\section{Statistical Analysis}

All the assays were carried out in triplicate and all the data were recorded as mean $\pm \mathrm{SD}$.

\section{RESULTS AND DISCUSSION}

\section{Analysis by HPLC and UPLC/Q-TOF MS}

The content of forsythiaside $\mathrm{A}$ in $\mathrm{F}$. suspensa leaves was determined by HPLC (Figures 2A,B). The content of B, C, D, and E elution solution was 73.93, 655.82, 18.34, and $12.37 \mathrm{mg} / \mathrm{ml}$, respectively while there was almost no forsythiaside A in A elution solution. The results showed that the method could effectively enrich the active components of phenethyl alcohol glycosides in leaves.

The chromatographic conditions and mass spectrometry conditions were optimized for analysis and displayed the total ion chromatogram (Figures 2C,D). 31 compounds were identified including 11 glycosides, eight flavonoids, three organic acids, three phenolic, three lignans, one phenylpropanoid, one terpenoid, and one other substance (Table 2). According to the results of UPLC/Q-TOF MS and HPLC, the main components of FC were glycosides and flavonoids, while the component with 

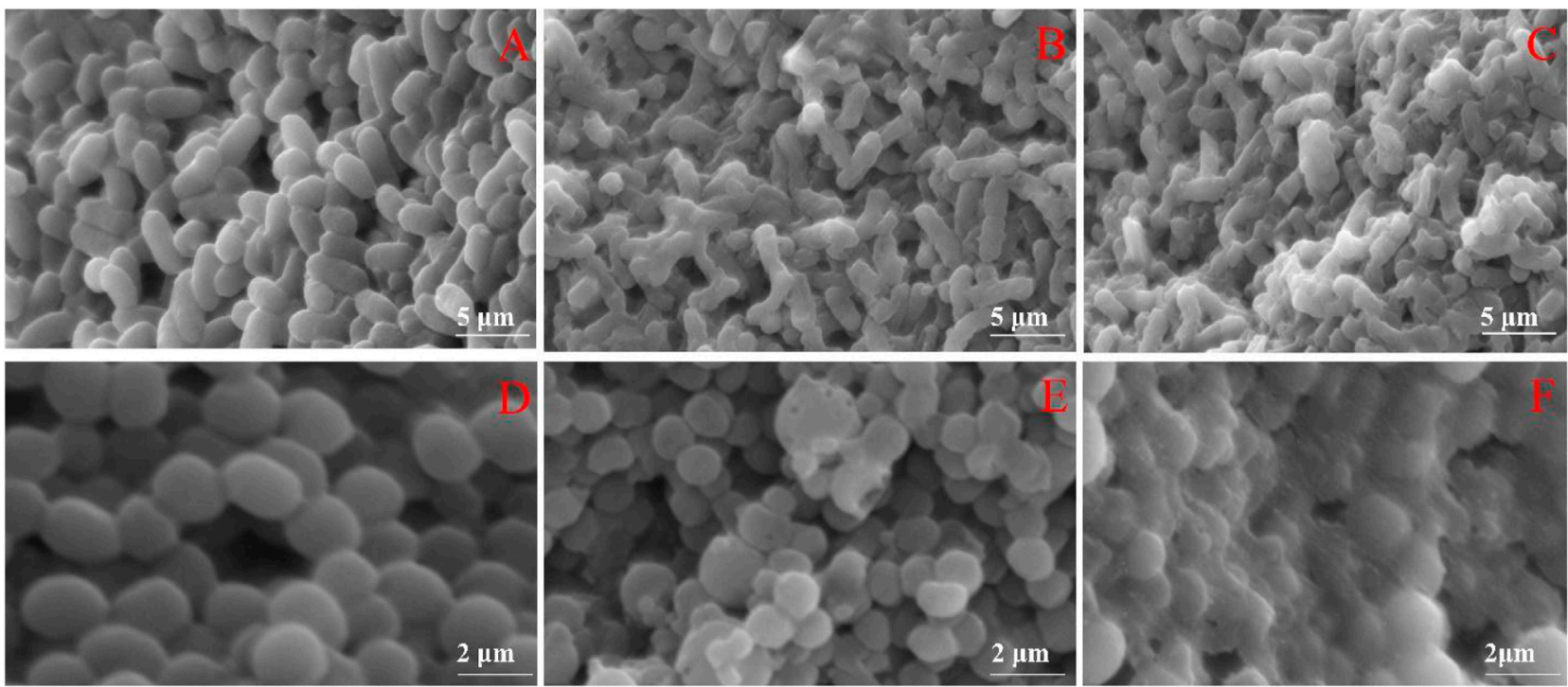

FIGURE 4 | Effects of FC on the morphology of tested bacteria (A): Untreated E. coli. (B): E. coli treated with MIC. (C): E. coli treated with 2MIC. (D): Untreated S. aureus. (E): S. aureus treated with MIC. (F): S. aureus treated with 2MIC).
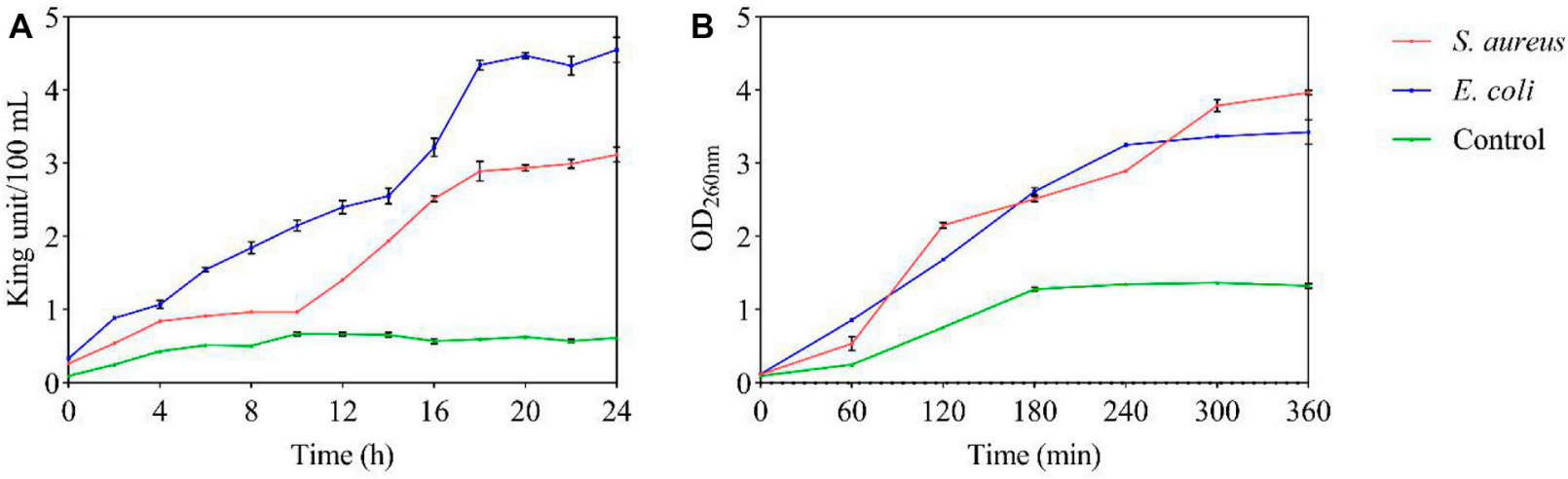

FIGURE 5 | Antibacterial mechanism of FC at MIC on test bacteria (A): Cell wall permeability; (B): Membrane integrity).

antibacterial activity in glycosides was phenylethanoid glycosides. Forsythoside A was used as the component with the highest content. The $\mathrm{MS}^{2}$ chromatogram and product ion spectrum of forsythiaside A is shown in Supplementary Figure S1. ABDE fraction did not show antibacterial activity due to the low content of active ingredients of phenylethanoid glycosides.

\section{Assay of Antibacterial Potential}

The in vitro antibacterial activity of FC against two bacteria was assessed based on the presence of inhibition zones (Table 3 and Supplementary Figure S2). The diameter of inhibition zone $>15 \mathrm{~mm}$ was indicated high sensitivity, $10-14 \mathrm{~mm}$ was moderate sensitivity, 6-9 mm was low sensitivity, and $5.0 \mathrm{~mm}$ has no antibacterial effect.

The FC showed antibacterial activity against $S$. aureus and E. coli. The MIC of S. aureus and E. coli was 7.81 and $3.91 \mathrm{mg} / \mathrm{ml}$, and the $\mathrm{MBC}$ was 7.81 and $15.63 \mathrm{mg} / \mathrm{ml}$.
By measuring the viability of the tested bacteria, their survival during the 300 min with FC treatment was inhibited. The growth of the two tested bacteria was inhibited at the MIC, and 50\% inhibition of cell viability was detected within $20 \mathrm{~min}$. After $210 \mathrm{~min}, 80 \%$ bacterial inhibition was observed, and all tested bacteria were completely inhibited by FC after $300 \mathrm{~min}$ (Figure 3A). According to the experimental results, FC has an inhibitory effect on the growth of the tested bacteria (Figure 3B). The control group has typical growth curve characteristics. The tested bacteria were always lower than the control group during the whole growth period, indicating that the FC was against $S$. aureus and E. coli.

\section{Assay of Antibacterial Potential}

Through SEM, it was observed that E. coli in the blank group had a regular rod shape, intact surface. The shape of most E. coli treated with FC became irregular, and shrinked to varying 

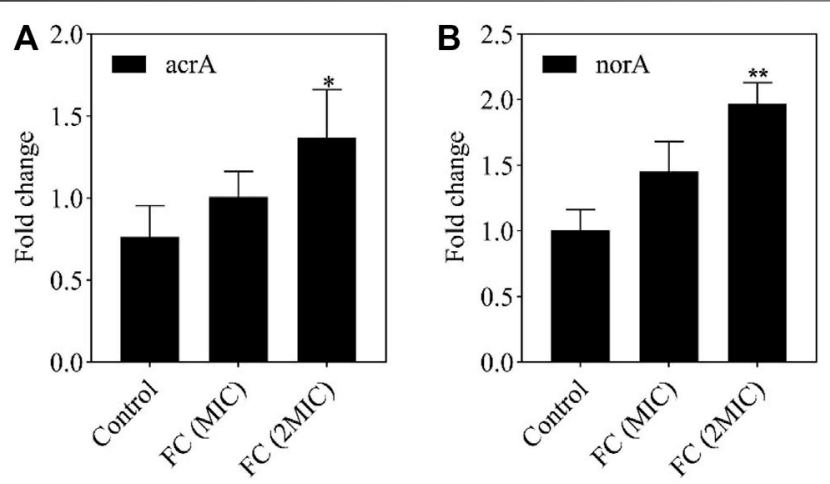

FIGURE 6 | The effect of MIC and 2MIC concentration FC on gene expression levels. The fold change in the expression level of acrA (A), norA (B) in the E. coli, S. aureus of different concentration (MIC, 2MIC) of FC group were compared to the control without FC treatment by using RT-PCR. Data from the RT-PCR analysis is represented as mean \pm SEM. By $t$-test analysis, ${ }^{\star} p<0.05,{ }^{\star \star} p<0.01$ comparing to the control group.

degrees. The shape of $S$. aureus in the blank group was a regular spherical shape, with complete cells and a smooth surface. After $S$. aureus was exposed to FC solution, its cell membrane appears pitted, shrunk, holes appear on the surface, which may even cause the cell to rupture and the contents to flow out. The changes of test bacteria may be caused by the destruction of the membrane and the loss of intracellular substances in E. coli and $S$. aureus caused by FC. (Figure 4).

AKP is an intracellular enzyme. Normally, its activity can not be detected outside the cell. However, when the cell wall or membrane is destroyed, the permeability is increased and then AKP leaks out of the cell (Bucekova et al., 2019). Such permeability change occurred in the presence of FC (Figure 5A), therefore, we conclude that FC can destroy the cell walls of $S$. aureus and E. coli. Proteins and nucleic acids are extremely important macromolecules for cells, providing cellular structure, function, and genetic information. According to the method of Paul, the absorbance of nucleic acids and proteins at $260 \mathrm{~nm}$ could be an indicator of membrane integrity (Bajpai et al., 2013; Paul et al., 2011; Hao et al., 2020). With time, the release of cellular components increased significantly at MIC (Figure 5B). This result indicated that FC affected the integrity of the membrane, causing nucleic acids and proteins to leak through the membrane, leading to cell death. Another possibility is that FC may have penetrated the cell membrane and free radicals were produced, which oxidize and damage lipids, proteins, and DNA (Bakkali et al., 2008).

An in-depth study of specific drug resistance mechanisms was outside the scope of this study. However, a targeted study of some drug delivery pumps with clear pump functions can be used to screen new antibacterial drugs and resistance inhibitors (Kaatz and Seo, 2004). The expression of the acrA gene can cause E. coli to be resistant to many drugs. The expression of the norA gene can cause $S$. aureus to be resistant to many drugs. Therefore, the expression of the active efflux gene acrA/norA plays a crucial role in the drug resistance of E. coli/S. aureus. The dissociation curve of RT-PCR indicated that the melting temperature of the amplification product is stable, the amplification product is single, the primer design is correct, there are no unspecific products, and the test results are accurate. As shown in Figure 6, the acrA and norA expression levels in the control group were lower than those in the FC treatment group. After different concentrations of FC treatment (MIC, 2MIC), the expression levels of acrA and norA proteins were up-regulated. We infer that the cellular damage caused by FC components can interfere with the development of drug resistance in these and possibly other bacteria. However, due to the complexity of the drug resistance mechanism, our team will conduct in-depth research on the antibacterial mechanism of F. suspensa leaves in the next step.

\section{CONCLUSION}

In this paper, MARs were used to enrich the active components of F. suspensa leaves, which had the advantages of being fast, efficient, economical, and recyclable. Compared with the traditional HPLC analysis, this research used UPLC/Q-TOF MS for the first time to identify 31 compounds in the extract of $F$. suspensa leaves, which deepened the understanding of their chemical constituents. At present, the research on $F$. suspensa leaves mainly focuses on the extraction, isolation, and structural identification of individual components, without the overall analysis and indepth study of its pharmacological effects and the antibacterial mechanism has not been clearly explained. In this article, the antibacterial effect of leaves and its antibacterial mechanism have entered in-depth research, including the determination of the inhibition zone diameter, MIC and MBC, the growth curve, viable counts, external morphology changes, permeability/ integrity of the cell wall/membrane, and changes in the expression of a cell membrane efflux pump gene. Taken together, our findings provide evidence that the extract of $\mathrm{F}$. suspensa leaves exhibited an antibacterial effect that involves damaging the bacterial cell membrane and raising bacterial cell wall permeability abnormally. This is conducive to more comprehensive utilization of medicinal plant resources.

\section{DATA AVAILABILITY STATEMENT}

The raw data supporting the conclusions of this article will be made available by the authors, without undue reservation.

\section{AUTHOR CONTRIBUTIONS}

$\mathrm{WW}, \mathrm{JH}$, and MZ designed experiments; MZ carried out experiments, analyzed experimental results, and wrote the manuscript. CW proofread the manuscript.

\section{SUPPLEMENTARY MATERIAL}

The Supplementary Material for this article can be found online at: https://www.frontiersin.org/articles/10.3389/fphar.2021.704260/ full\#supplementary-material 


\section{REFERENCES}

Bajpai, V. K., Sharma, A., and Baek, K.-H. (2013). Antibacterial Mode of Action of Cudrania Tricuspidata Fruit Essential Oil, Affecting Membrane Permeability and Surface Characteristics of Food-Borne Pathogens. Food control 32, 582-590. doi:10.1016/j.foodcont.2013.01.032

Bakkali, F., Averbeck, S., Averbeck, D., and Idaomar, M. (2008). Biological Effects of Essential Oils-Aa Review. Food Chem. Toxicol. 46, 446-475. doi:10.1016/ j.fct.2007.09.106

Bucekova, M., Jardekova, L., Juricova, V., Bugarova, V., Di Marco, G., Gismondi, A., et al. (2019). Antibacterial Activity of Different Blossom Honeys: New Findings. Molecules 24, 1573. doi:10.3390/molecules24081573

Chen, C. C., Chen, H. Y., Shiao, M. S., Lin, Y. L., Kuo, Y. H., and Ou, J. C. (1999). Inhibition of Low Density Lipoprotein Oxidation by Tetrahydrofurofuran Lignans from Forsythia Suspensa and Magnolia Coco. Planta Med. 65, 709-711. doi:10.1055/s-1999-14093

Filippini, M., Ortelli, C., Svercel, M., and Bagheri, H. C. (2011). Interspecies Variation in Survival and Growth of Filamentous Heterotrophic Bacteria in Response to UVC Radiation. J. Photochem. Photobiol. B 103, 234-242. doi:10.1016/j.jphotobiol.2011.03.018

Han, J., Zhao, S., Ma, Z., Gao, L., Liu, H., Muhammad, U., et al. (2017). The Antibacterial Activity and Modes of LI-F Type Antimicrobial Peptides against Bacillus Cereus In vitro. J. Appl. Microbiol. 123, 602-614. doi:10.1111/jam.13526

Han, X., Piao, X. S., Zhang, H. Y., Li, P. F., Yi, J. Q., Zhang, Q., et al. (2012). Forsythia Suspensa Extract Has the Potential to Substitute Antibiotic in Broiler Chicken. Asianaustralas J. Anim. Sci. 25, 569-576. doi:10.5713/ajas.2011.11425

Hao, Y., Huo, J., Wang, T., Sun, G., and Wang, W. (2020). Chemical Profiling of Coptis Rootlet and Screening of its Bioactive Compounds in Inhibiting Staphylococcus aureus by UPLC-Q-TOF/MS. J. Pharm. Biomed. Anal. 180, 113089. doi:10.1016/j.jpba.2019.113089

Jian-rui, S., Da-hong, W., Zhi-jun, Q., and Jiang-feng, Y. (2017). Simultaneous Extraction Purification of Forsythoside A, Rutin and Phillyrin from Forsythia Suspensa Leaves. Food Sci. 38, 200-205.

Kaatz, G. W., and Seo, S. M. (2004). Effect of Substrate Exposure and Other Growth Condition Manipulations on norA Expression. J. Antimicrob. Chemother. 54, 364-369. doi:10.1093/jac/dkh341

Kim, M. S., Na, H. J., Han, S. W., Jin, J. S., Song, U. Y., Lee, E. J., et al. (2003). Forsythia Fructus Inhibits the Mast-Cell-Mediated Allergic Inflammatory Reactions. Inflammation 27, 129-135. doi:10.1023/a:1023865727780

Lee, S. E., Lim, C., Ahn, S. C., and Cho, S. (2017). A Study of the Anti-cancer Effects of the Hexane Fraction of the Methanol Extract of Forsythiae Fructus. Pharmacogn Mag. 13, 719-724. doi:10.4103/0973-1296.211079

Livak, K. J., and Schmittgen, T. D. (2001). Analysis of relative gene expression data using real-time quantitative PCR and the 2(-Delta Delta $\mathrm{C}(\mathrm{T})$ ) Method. Methods 25 (4), 402-8. doi:10.1006/meth.2001.1262
Mellegård, H., Strand, S. P., Christensen, B. E., Granum, P. E., and Hardy, S P. (2011). Antibacterial Activity of Chemically Defined Chitosans: Influence of Molecular Weight, Degree of Acetylation and Test Organism. Int. J. Food Microbiol. 148, 48-54. doi:10.1016/ j.ijfoodmicro.2011.04.023

Monteiro, M. B., Santos-Bezerra, D. P., Thieme, K., Passarelli, M., Machado, U. F., Lin, C. J., et al. (2016). Optimization of Total RNA Isolation from Human Urinary Sediment. Clin. Chim. Acta 462, 158-161. doi:10.1016/ j.cca.2016.09.018

Paul, S., Dubey, R. C., Maheswari, D. K., and Kang, S. C. (2011). Trachyspermum Ammi (L.) Fruit Essential Oil Influencing on Membrane Permeability and Surface Characteristics in Inhibiting Food-Borne Pathogens. Food Control 22, 725-731. doi:10.1016/j.foodcont.2010.11.003

Qiang, X., Yu-huan, L., Shu-ping, M., Jing, L., and Xiu-hua, X. (2014). Effects of Carvacrol on Escherichia coli and Staphylococcus aureus Membrane. Sci. Technol. Food Industry 35 (23), 54-58. doi:10.13386/j.issn10020306.2014.23.002

Tian, X. Y., Li, M. X., Lin, T., Qiu, Y., Zhu, Y. T., Li, X. L., et al. (2021). A Review on the Structure and Pharmacological Activity of Phenylethanoid Glycosides. Eur. J. Med. Chem. 209, 112563. doi:10.1016/ j.ejmech.2020.112563

Wang, Z., Xia, Q., Liu, X., Liu, W., Huang, W., Mei, X., et al. (2018). Phytochemistry, Pharmacology, Quality Control and Future Research of Forsythia Suspensa (Thunb.) Vahl: A Review. J. Ethnopharmacol 210, 318-339. doi:10.1016/j.jep.2017.08.040

Xiao-Fang, L., Xiao-Qiang, F., Sheng, Y., and Yuan-Cheng, Z. (2016). Antibacterial Characteristics and Mechanism of Chitosan-Metal Complexes. Natural Product. Research Development 28, 17-22. doi:10.16333/j.1001-6880.2016.1.004

Conflict of Interest: The authors declare that the research was conducted in the absence of any commercial or financial relationships that could be construed as a potential conflict of interest.

Publisher's Note: All claims expressed in this article are solely those of the authors and do not necessarily represent those of their affiliated organizations, or those of the publisher, the editors and the reviewers. Any product that may be evaluated in this article, or claim that may be made by its manufacturer, is not guaranteed or endorsed by the publisher.

Copyright ( 12022 Zhou, Huo, Wang and Wang. This is an open-access article distributed under the terms of the Creative Commons Attribution License (CC BY). The use, distribution or reproduction in other forums is permitted, provided the original author(s) and the copyright owner(s) are credited and that the original publication in this journal is cited, in accordance with accepted academic practice. No use, distribution or reproduction is permitted which does not comply with these terms. 